\title{
VEGETATION AND CLIMATE CHANGES DURING THE BRONZE AND IRON AGES ( 3600-600 BCE) IN THE SOUTHERN LEVANT BASED ON PALYNOLOGICAL RECORDS
}

\author{
Dafna Langgut ${ }^{1}$ Israel Finkelstein ${ }^{2} \cdot$ Thomas Litt $^{3} \cdot$ Frank Harald Neumann $^{4} \bullet$ Mordechai Stein $^{5}$
}

\begin{abstract}
This article presents the role of climate fluctuations in shaping southern Levantine human history from 3600 to $600 \mathrm{BCE}$ (the Bronze and Iron Ages) as evidenced in palynological studies. This time interval is critical in the history of the region; it includes two phases of rise and decline of urban life, organization of the first territorial kingdoms, and domination of the area by great Ancient Near Eastern empires. The study is based on a comparison of several fossil pollen records that span a north-south transect of $220 \mathrm{~km}$ along the southern Levant: Birkat Ram in the northern Golan Heights, Sea of Galilee, and Ein Feshkha and Ze'elim Gully both on the western shore of the Dead Sea. The vegetation history and its climatic implications are as follows: during the Early Bronze Age I ( 3600-3000 BCE) climate conditions were wet; a minor reduction in humidity was documented during the Early Bronze Age II-III ( 3000-2500 BCE). The Intermediate Bronze Age ( 2500-1950 BCE) was characterized by moderate climate conditions, however, since $\sim 2000$ BCE and during the Middle Bronze Age I ( 1950-1750 BCE) drier climate conditions were prevalent, while the Middle Bronze Age II-III $(\sim 1750-1550$ BCE) was comparably wet. Humid conditions continued in the early phases of the Late Bronze Age, while towards the end of the period and down to $\sim 1100 \mathrm{BCE}$ the area features the driest climate conditions in the timespan reported here; this observation is based on the dramatic decrease in arboreal vegetation. During the period of $\sim 1100-750 \mathrm{BCE}$, which covers most of the Iron Age I ( 1150-950 BCE) and the Iron Age IIA ( 950-780 BCE), an increase in Mediterranean trees was documented, representing wetter climate conditions, which followed the severe dry phase of the end of the Late Bronze Age. The decrease in arboreal percentages, which characterize the Iron Age IIB ( 780-680 BCE) and Iron Age IIC ( $\sim 680-586$ BCE), could have been caused by anthropogenic activity and/or might have derived from slightly drier climate conditions. Variations in the distribution of cultivated olive trees along the different periods resulted from human preference and/or changes in the available moisture.
\end{abstract}

\section{INTRODUCTION}

Due to the occurrence of different vegetation zones that follow steep north-south and west-east precipitation gradients, the southern Levant is a sensitive region for tracing links between climate and cultural changes, featuring Mediterranean (precipitation $>400 \mathrm{~mm} / \mathrm{yr}$ ), semi-arid steppe IranoTuranian ( 400-200 mm/yr), and desert Saharo-Arabian (precipitation $<200 \mathrm{~mm} / \mathrm{yr}$ ) zones (Zohary 1973, 1982; Figure 1). The region went through significant changes in climate patterns during the Late Holocene. These changes were accompanied by transformations in settlement and demographic patterns (e.g. Migowski et al. 2006; Neumann et al. 2007a; Kaniewski et al. 2010; Litt et al. 2012; Langgut et al. 2013). The question of how environmental changes affected human activity in this area in antiquity has been debated (compare Rambeau 2010). This article includes the results of recent research efforts to establish the vegetation history of the Bronze and Iron Ages ( 3600$600 \mathrm{BCE}$ ) based on high-resolution and well-dated fossil pollen records. This time interval features cycles of rise and fall of urban cultures, the emergence and collapse of the territorial kingdoms documented in the Hebrew Bible and other Ancient Near Eastern records, and periods of imperial rule. It also features sharp settlement oscillations, including human movements between the Mediterranean, semi-arid, and desert environments that could have resulted from climate fluctuations.

The study of fossil pollen grains is a powerful tool in the reconstruction of past vegetation and climate history (e.g. Bryant 1989). Several palynological records that cover the Bronze and Iron Ages are available for the southern Levant. Four of them are presented and discussed below (Figure 1):

1. Laboratory for Archaeobotany and Ancient Environments, Institute of Archaeology, Tel Aviv University,

P.O. Box 39040, Tel Aviv 6997801, Israel. Corresponding author. Email: langgut@post.tau.ac.il.

2. Institute of Archaeology, Tel Aviv University, Tel Aviv 6997801, Israel.

3. Steinmann Institute of Geology, Mineralogy and Paleontology, University of Bonn, Nussallee 8, 53115 Bonn, Germany.

4. Forschungsstelle für Paläobotanik, Westfälische Wilhelms-Universität Münster, Heisenbergstr. 2, 48149 Münster, Germany.

5. Geological Survey of Israel, 30 Malkhe Israel St., Jerusalem 95501, Israel.

The Iron Age in Israel: The Exact and Life Sciences Perspective

Edited by Israel Finkelstein, Steve Weiner, and Elisabetta Boaretto 


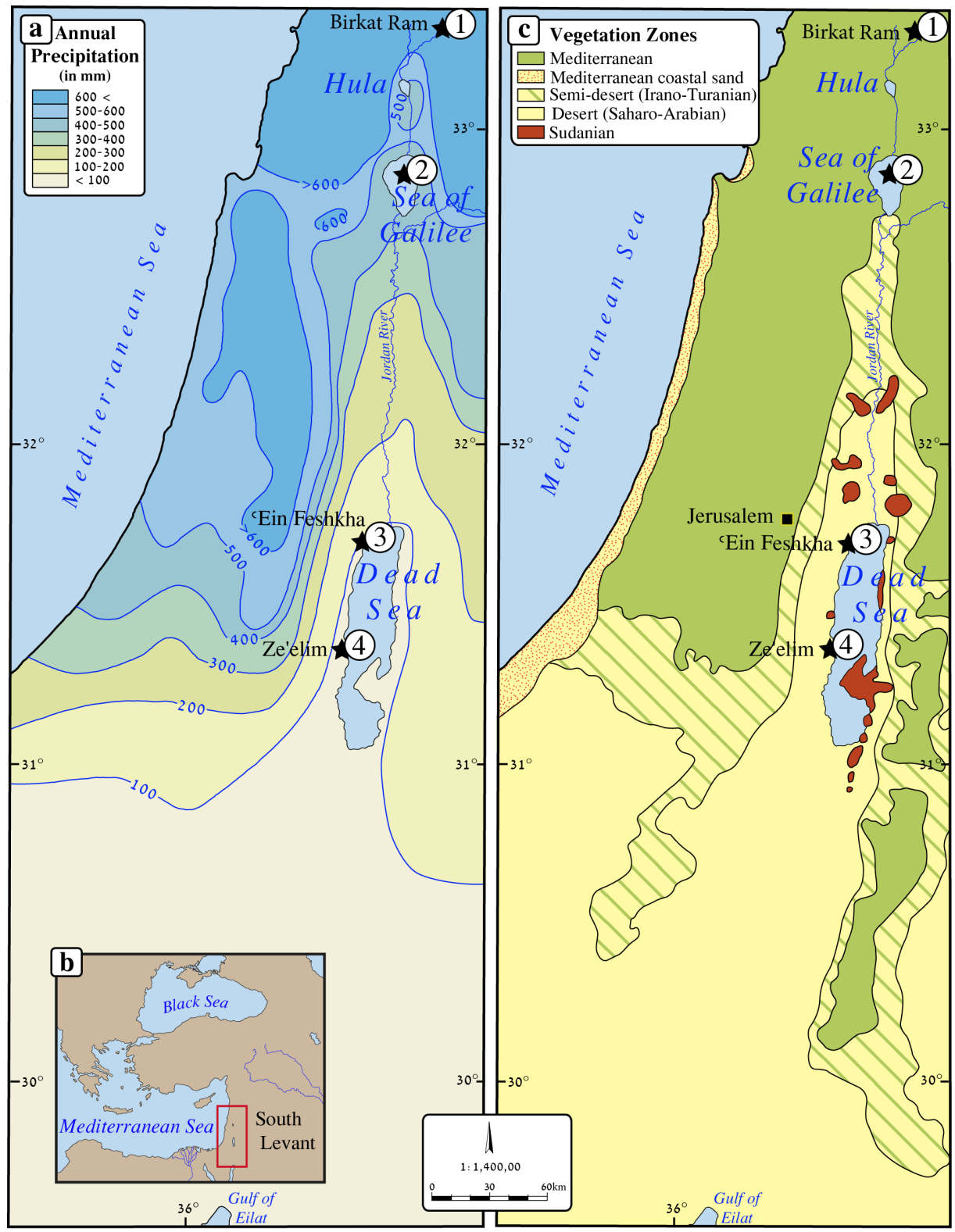

Figure 1 (a) Rainfall isohyets of the south Levantine region (after Srebro and Soffer 2011), with the location of the four fossil pollen records discussed in this paper: 1. Birkat-Ram (Schwab et al. 2004; Neumann et al. 2007b); 2. Sea of Galilee (Langgut et al. 2013; this study, Figure 3); 3. Ein Feshkha (Neumann et al. 2007a, 2009), and 4. Ze'elim Gully (Neumann et al. 2007a; Langgut et al. 2014a); (b) the position of the southern Levant in the Eastern Mediterranean; (c) phytogeographic zones.

Birkat Ram (Schwab et al. 2004; Neumann et al. 2007b), Sea of Galilee (Langgut et al. 2013; this study), Ein Feshkha (Neumann et al. 2007a, 2009), and Ze'elim Gully (Neumann et al. 2007a; Langgut et al. 2014a). These records were chosen because of their relatively robust chronological framework and high pollen sampling resolution (only a few decades interval between samples). Other pollen diagrams from the region are not presented here since they were either sampled in 
lower resolution [e.g. Litt et al. (2012) at the Dead Sea analyzed samples in 180/200-yr intervals between samples], and/or because they suffer from chronological uncertainties (Baruch 1986, 1990, 1993; Baruch and Bottema 1999; van Zeist et al. 2009; several studies discuss the chronological problems of some of the pollen diagrams from the region, e.g. Cappers et al. 1998; Meadows 2005; Neumann et al. 2010).

This study therefore spans a north-south transect of $220 \mathrm{~km}$ of the southern Levant, which features a north-south precipitation gradient of $\sim 1000 \mathrm{~mm}$ of annual rainfall as well as a sharp topographic gradient. While Birkat Ram, located in a volcanic maar, is located at $940 \mathrm{~m}$ above msl (mean sea level), the Sea of Galilee and the Dead Sea-which comprise morphotectonic depressions along the Dead Sea Transform (Neev and Emery 1995; Stein 2001, 2014a,b) - are situated at 200 and $400 \mathrm{~m}$ below sea level ( $\mathrm{m}$ bsl), respectively.

In addition to paleoclimate reconstruction, this research also aims at tracing evidence of human interference in natural vegetation as reflected in the pollen curves: agricultural activity, grazing, deforestation, abandonment of fields, and soil erosion.

\section{CURRENT CLIMATE AND VEGETATION}

Annual rainfall in the southern Levant is high on the coast and in the north, and diminishes to the south and east (Ziv et al. 2006; Dayan et al. 2007), where the north Sinai coastline forms the southern limit in which rain clouds can form in large masses (Zangvil and Druian 1990). East of the Mediterranean, the influence of the Mediterranean humidity drops sharply, also due to the orographic effect of the mountain ranges, which create a rain shadow, the Judean Desert. As a result, the southern Levant is composed of three main phytogeographical zones (Zohary 1962, 1973) (Figure 1b): (1) the Mediterranean, (2) the Irano-Turanian, and (3) the Saharo-Arabian (which also includes some tropical plants that belong to the Sudanian vegetation).

1. The Mediterranean region runs along the coast and its adjacent mountainous areas (Galilee, Carmel Ridge, Samaria, and Judea). This vegetation zone features Mediterranean maquis/forest with typical evergreen trees such as Quercus callipprinos, Olea europaea, and Pinus halepensis and some deciduous trees (e.g. Quercus boissieri, Q. ithaburensis, and Pistacia palaestina). In the understory of forests or in open fields, dwarf-shrubs as well as many herbaceous species are common. This territory receives more than $400 \mathrm{~mm}$ rainfall annually and is generally influenced by the Mediterranean climatic system together with some regional orographic phenomena. The Israeli coastal plain occupies a mix of Mediterranean and desert plants due to its sandy soil and saline environment. This sandy strip is dominated by different species of Poaceae, Chenopodiaceae, Artemisia monosperma, and Ephedra.

2. The Irano-Turanian phytogeographic region runs from the coastal plain near Gaza to the Negev Highlands and the southern edge of the Judean Highlands and then continues northward via the central Jordan Valley to the Sea of Galilee. This is an almost tree-less landscape with semi-arid vegetation, often described as steppe. Different species of Poaceae and Chenopodiaceae are the main vegetal components of this region as well as Artemisia herba-alba. The annual rainfall is $200-400 \mathrm{~mm}$ on average and is due mainly to western Mediterranean depressions. The region is also characterized by relatively broad seasonal and daily temperature distributions.

3. The Saharo-Arabian territory occupies most of the Negev Desert, which lies within the world desert belt $\left(30^{\circ} \mathrm{N}\right)$. The vegetation is typified by relatively low species diversity and is dominated by many members of the Chenopodiaceae, Zygophyllum dumosum, grasses, and Tamarix spp. This region has a typical desert climate: the mean annual rainfall does not exceed $200 \mathrm{~mm}$ 
and is usually lower than $100 \mathrm{~mm}$. Seasonal and daily temperature distributions are broad. This zone is influenced by southern and southeastern synoptic systems, which are widespread in the spring and autumn, as well as by the western Mediterranean depressions, which mainly influence the northern part of the Negev Desert. Within these desert plants' geographical area, the Sudanian territory with tropical elements occurs along the shores of the Dead Sea, in the Arabah Valley and in the central Jordan Valley (up to $\sim 80 \mathrm{~km}$ north of the Dead Sea). Some of the tropical plants are linked to freshwater springs or wadi beds; they include Acacia, Ziziphus spinachristi, and Salvadora persica (Zohary 1962; Shmida and Or 1983; Al-Eisawi 1996).

\section{SOUTHERN LEVANT POLLEN RECORDS}

\section{Birkat Ram}

Birkat Ram, in the foothills of Mount Hermon, comprises a small maar lake that has occupied this volcanic depression since the last interglacial period (the TAHAL borehole, which was performed in 1968, penetrated $120 \mathrm{~m}$ and reached the basaltic flow at the bottom of the lacustrine sequence; Singer and Ehrlich 1978). The paleohydrological importance of Birkat Ram stems from its being a "sampler" of the Mount Hermon hydrological system; in general, maar lakes comprises a "delicate" regional tracer because of the lack of input water from major river and streams (e.g. Lamb et al. 2000; Lamb 2001). In 1999, a joint team of GFZ-Potsdam and the Hebrew University carried out several drills under water at a depth of $1.5 \mathrm{~m}$ (Schwab et al. 2004). This very shallow depth could not support deep drilling and the expedition yielded cores that were only several meters long. They were used to prepare a 543-cm-long composite profile. Correlations between the cores were established by high-resolution magnetic susceptibility, which was independently improved by palynological observations (Schwab et al. 2004; Neumann et al. 2007b). The compiled sedimentary record is characterized by a relatively homogenous lithology of detrital marls and diatoms. Eighteen samples of organic debris were accelerator mass spectrometry (AMS) radiocarbon dated and a chronological framework was established from $\sim 4500$ BCE to modern times (Schwab et al. 2004; Neumann et al. 2007b). The palynological investigation was conducted at an average sample interval of $\sim 4 \mathrm{~cm}$ from the Bronze to the Iron Ages. Considering a uniform sedimentation rate in the composite core, this would imply that every sample represents on average $75 \mathrm{yr}$.

\section{Sea of Galilee (Lake Kinneret)}

The Sea of Galilee receives its water from the Jordan River and some other shorter rivers running from the Galilee Mountains and the Golan Heights (Figure 2). The southern part of the lake comprises a shallow body of water, a few meters deep, while the northern part (where Research Station A is located) reaches a water depth of $40 \mathrm{~m}$. During most of the Holocene, the Sea of Galilee stood at $\sim 212 \mathrm{~m}$ bsl, yet there were periods when the lake level declined and the shallower southern part was exposed (Hazan et al. 2005; Stein 2014a). However, no evidence exists for a full desiccation of the lake during the past 10,000 yr. Thus, it appears that sedimentation in its northern part has been continuous.

The drilling campaign performed during the spring of 2010 recovered an 18-m core from the bottom of the lake near Research Station A. Details on the description of the compiled cores are given by Schiebel (2013). ${ }^{14} \mathrm{C}$ dating of organic debris from the core indicates that the drilled sediment sequence covers almost the entire Holocene (Schiebel 2013). The time interval of the Bronze to Iron Ages comprises $5.5 \mathrm{~m}$ of the $18-\mathrm{m}$ profile, and is characterized by a relatively homogenous lithology. This specific interval (composite depth of 458.8-1006.6 cm) was sampled for palynological analysis at 10-cm intervals (a total of 56 samples). A concise palynological diagram of the Bronze and Iron Ages was presented by Langgut et al. (2013); a more detailed diagram is given in Figure 3 
and the online Appendix. Six samples of terrestrial, short-lived organic debris were extracted from the Bronze and Iron Age sediment section and were AMS ${ }^{14} \mathrm{C}$ dated. The chronology (age-depth model) is presented in Langgut et al. (2013), which covers the time interval of 3150-500 BCE. Assuming a uniform sedimentation rate in this interval, the resolution of the palynological sampling would be a sample per $\sim 40 \mathrm{yr}$.

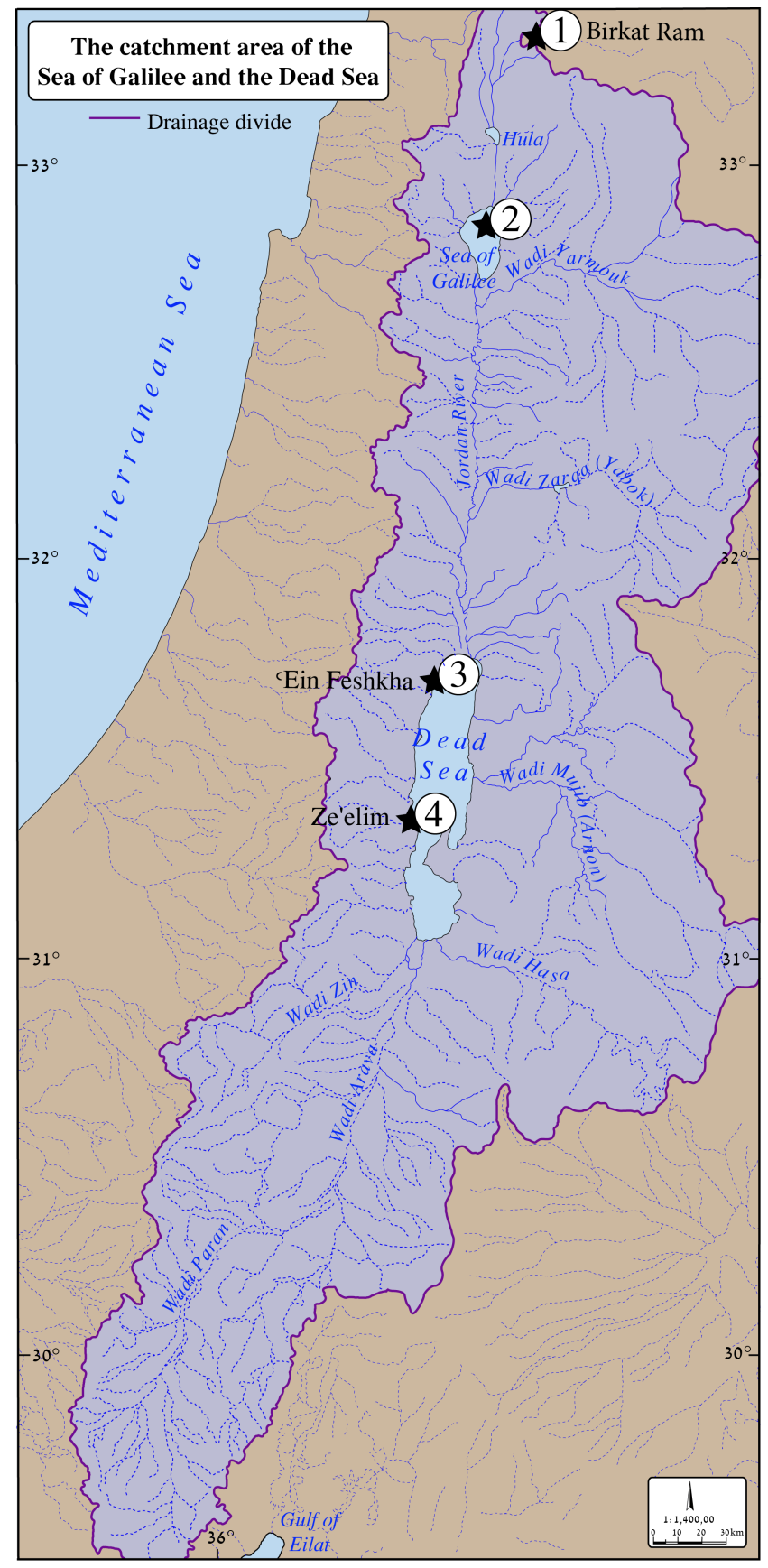

Figure 2 The catchment area of the Sea of Galilee and the Dead Sea with the watershed divide line of the region. 


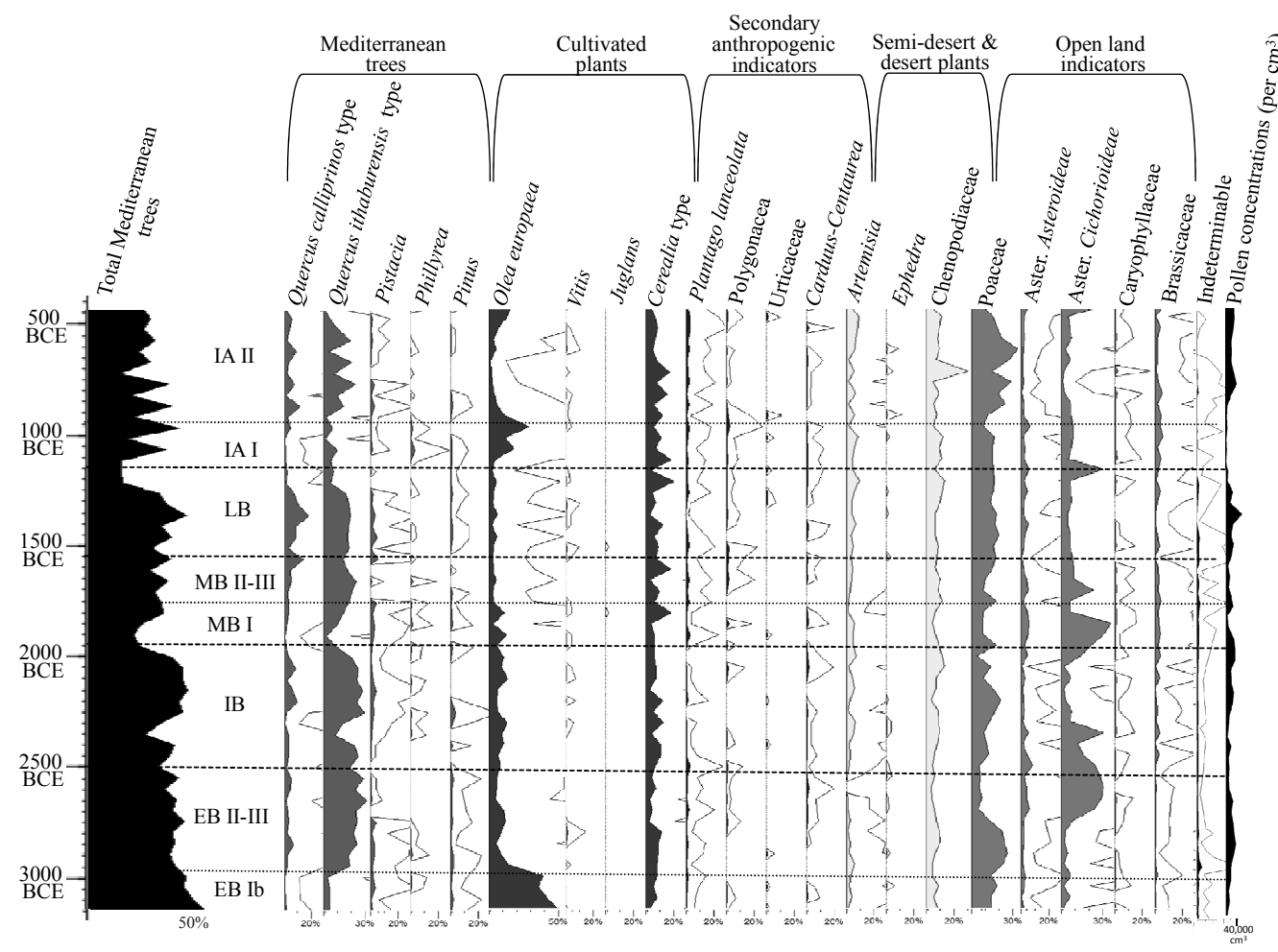

Figure 3 Simplified pollen diagram of the Sea of Galilee record during the Bronze and Iron Ages. A 10-fold exaggeration is used to show changes in low taxa percentages. The palynological diagram was divided into five main groups based on taxa geographical origin and on ecological and cultural characteristics (see online Appendix). EB = Early Bronze Age; IB = Intermediate Bronze Age; MB = Middle Bronze Age; LB = Late Bronze Age; IA = Iron Age .

\section{Ein Feshkha}

A 5.85-m-long outcrop was sampled at the Ein Feshkha National Reserve from the gully's wall (Neumann et al. 2007a, 2009). The site is located at the northwest side of the Dead Sea and is affected by water and sediments that flow from the central part of the Judean Hills. The profile is predominantly lacustrine, composed mainly of fine detrital particles and sequences of laminated couplets of aragonite and silty detritus or triplets of detritus, aragonite, and gypsum (described in Neumann et al. 2007a). The chronological framework of the section (an age-depth model) was obtained by AMS ${ }^{14} \mathrm{C}$ dating of organic debris (Neumann et al. 2007a) that was later integrated with ages of historical earthquakes that were correlated to disturbed sedimentary structures in the section described as seismites (Kagan et al. 2011). The record begins at about $1400 \mathrm{BCE}$, that is, in the middle of the Late Bronze Age, and was sampled for pollen investigation in resolution of $10 \mathrm{~cm}$ or less, which represents $\sim 30$ yr between samples.

\section{Ze'elim Gully}

The Ze'elim terrace is located east of the Masada plain on the southwestern side of the northern deep basin of the Dead Sea, very close to the sill that separates the southern and northern basins [at the elevation of 402-403 m bsl, Bookman (Ken Tor) et al. 2004]. The Ze'elim Gully, the origin of the outcrop, dissected the terrace. It has been the focus of ongoing investigation since 1992, following the continuous anthropogenic retreat of the lake (currently $>100 \mathrm{~cm} / \mathrm{yr}$ ). The Ze'elim River (Nahal Ze'elim) that enters the Dead Sea at the Ze'elim terrace drains the southern part of the 
Judean Desert, carrying waters and sediments that originate on the eastern flank of the central highlands ridge. Description of the stratigraphy, sedimentology, ${ }^{14} \mathrm{C}$ chronology and palynology of the Ze'elim sections is given in several papers [Ken-Tor et al. 2001; Bookman (Ken-Tor) et al. 2004; Neumann et al. 2007a; Kagan et al. 2011, 2015; Langgut et al. 2014a]. Within the framework of the current project, we returned to the Ze'elim Gully exposures in 2010 and described several new sediment wall-profiles, each $50 \mathrm{~cm}$ long, focusing on the section that covers the Bronze and Iron Ages (Langgut et al. 2014a). The 2010 sediment outcrop is located near the section studied previously by Neumann et al. (2007a), who analyzed the pollen record in lower and irregular resolution. Yet, the proximity to this older profile (which has since collapsed) enabled us to perform a stratigraphic and chronological correlation (Langgut et al. 2014a; Kagan et al. 2015). The chronology of the entire integrated sediment sequence (the ZA-Pcomp Ze'elim section) is based on $11{ }^{14} \mathrm{C}$ AMS dates of short-lived organic material and on the identification of a seismic event dated to the 8th century BCE (the "Amos earthquake") (Kagan et al. 2011). The ZA-compiled profile covers the time interval of $\sim 2500-500 \mathrm{BCE}$ - from the beginning of the Intermediate Bronze Age to the end of the Iron Age and beyond. It was sampled for pollen analysis at $\sim 5$-cm intervals, which represents a few decades between samples (Langgut et al. 2014a).

\section{Pollen Indicators}

Four main pollen curves were chosen in order to compare the palynological records (Figure 4):

1. Quercus (oak): This group includes two oak pollen types: evergreen and deciduous. While $Q$. calliprinos is the only evergreen oak tree in Israel, among the Q. ithaburensis type some may have been $Q$. boissieri, which is a deciduous oak species of the upper elevations of the highlands, and some Q. ithaburensis, a tree typical of lower elevations (Zohary 1973). However, the two deciduous oak species are palynologically indistinguishable.

2. Pinus halepensis (Aleppo pine) is the only naturally occurring pine species in Israel (WeinsteinEvron and Lev-Yadun 2000). In historical periods, pine was the first tree of the Mediterranean maquis/forest that established itself naturally in areas disturbed by human activities where it colonizes abandoned fields (Baruch 1986, 1990; Lev-Yadun and Weinstein-Evron 2002; Danin 2004). Pines have excellent pollen dispersal efficiency; especially in non-forested landscapes, they are often over-represented due to long-distance transport (e.g. Sivak 1975; Faegri and Iversen 1989). Pollen of $P$. halepensis cannot be differentiated from pollen of other Pinus species (e.g. Eastwood et al. 1998).

3. Olea europaea (olive) was among the most important cultivated plants in the region since the Early Bronze Age (Zohary et al. 2012). It grows today in the southern Levant in the Mediterranean territory mostly as a cultivated tree (Zohary 1973; Zohary et al. 2012). The wild olive is a minor component of the native Mediterranean Quercus calliprinos-Pistacia palaestina association as evident by Pleistocene and Early Holocene pollen diagrams (Horowitz 1979; Weinstein-Evron 1983; Kadosh et al. 2004; van Zeist and Bottema 2009; Langgut et al. 2011). Based on both palynological evidence (Baruch 1990; Neumann et al. 2007a,b; van Zeist et al. 2009; Litt et al. 2012) and archaeological finds (e.g. Zohary and Spiegel-Roy 1975; Epstein 1978, 1993, 1998; Gophna and Kislev 1979; Neef 1990; Eitam 1993), it is obvious that by the Early Bronze Age Olea had already been intensely cultivated in the southern Levant. This evergreen wind-pollinated tree has a very efficient pollen dispersal system (e.g. Baruch 1993) and has a strong response to cessation and resumption of orchard cultivation (resulting in dramatic fluctuations in pollen production following abandonment or rehabilitation of olive orchards). It is therefore considered as a reliable marker for identifying agricultural activities in antiquity (Langgut et al. 2014b). 
4. Mediterranean arboreal pollen: This group sums up all the Mediterranean trees and shrubs and is dominated by evergreen and deciduous oaks while other Mediterranean trees appear in lower percentages (e.g. Phillyrea, Pistacia spp., Pinus halepensis, and Ceratonia siliqua). Cultivated olives were combined within the natural elements of the Mediterranean forest (the Mediterranean arboreal pollen; gray pollen curves in Figure 4), which evidently includes wild olive trees, while desert trees such as Acacia and Tamarix were excluded. In general, the Mediterranean trees and shrubs require at least $350 \mathrm{~mm}$ of annual rainfall in order to thrive (e.g. Zohary 1973). Therefore, fluctuations in the Mediterranean arboreal pollen curve can provide information on climate, especially in the climate-sensitive areas located on the fringe of the Mediterranean zone.

\section{VEGETATION HISTORY, CLIMATE CHANGES, AND HUMAN IMPACT}

Each of the periods is discussed below for its paleoenvironmental reconstruction (both natural and anthropogenic) (Figure 4), integrating the relevant archaeological and textual evidence. The dating of the periods follows the ${ }^{14} \mathrm{C}$ results for Levantine sites from the last decade (Regev et al. 2012 for the Early Bronze Age and the transition to the Intermediate Bronze Age; Finkelstein and Piasetzky 2010; Toffolo et al. 2014 for the Iron Age); the transition from Middle to Late Bronze Age, currently broadly fixed in the mid-16th century BCE, is yet to be ${ }^{14} \mathrm{C}$ dated (Bietak 2002 for the beginning of the Middle Bronze Age). Within our north-south palynological transect, decreasing percentages of the total Mediterranean trees indicate the shrinkage of the Mediterranean maquis/forest and the shifting of the semi-arid boundaries to the north and west due to less available moisture (Figure 1c); increasing values of the Mediterranean pollen tree indicate the opposite. The pollen records from the Sea of Galilee and the Dead Sea are sensitive to the conditions in both the Mediterranean area and the Irano-Turanian vegetation belt, as the two lakes collect wind-driven pollen from these two adjacent zones. In addition to airborne pollen, they receive fluvially transported pollen from large sectors of the southern Levant - mainly through the Jordan River, but also via local streams (Figure 2). Therefore, the southern pollen records (Sea of Galilee, Ein Feshkha, and Ze'elim; Figures $4 \mathrm{~b}-\mathrm{d}$ ) are more sensitive recorders of climate fluctuations than the northernmost pollen record from Birkat Ram (Figure 4a), which is located in an area that receives more than $1000 \mathrm{~mm}$ of annual rainfall (Srebro and Soffer 2011). While the Birkat Ram and the Sea of Galilee records begin during the Early Bronze Age, the Ze'elim profile begins in the Intermediate Bronze Age ( 2500 BCE) and the Ein Feshkha record begins only in the middle of the Late Bronze Age ( 1400 BCE). In addition to climate fluctuations, changes in vegetation distribution can result from human interference, such as the spread of agriculture, grazing, clearance of wood, and soil erosion. Therefore, in interpreting the palynological transect we are taking into account pollen grains that may point to the occurrence of these activities.

\section{Early Bronze Age ( 3600-2500 BCE)}

Two palynological diagrams are available for this period (Figures 4a,b) - Birkat Ram and the Sea of Galilee (the latter begins only in $\sim 3150 \mathrm{BCE}$, corresponding to the later phase of the Early Bronze Age I). The Mediterranean arboreal pollen curve, including olive trees, appears in its highest percentages, indicating that the Early Bronze Age I ( $\sim 3600-3000$ BCE) was the most humid phase in the Bronze and Iron Ages. This period also features the highest frequencies of olive trees (in Birkat Ram $\sim 10 \%$ and in the Sea of Galilee up to $50 \%$ ), representing the development of a specialized economy focused on olive orchards and their secondary products (Neumann et al. 2007b; Langgut et al. 2013). Settlement activity in northern Samaria and the western Jezreel Valley reached a peak during the Early Bronze Age I (Finkelstein and Gophna 1993; Finkelstein et al. 2006, respectively). The settlement pattern in the highlands represents dramatic intensification of the olive culture. Evidence from the southern Coastal Plain and the Nile Delta attests to strong trade relations with Egypt 

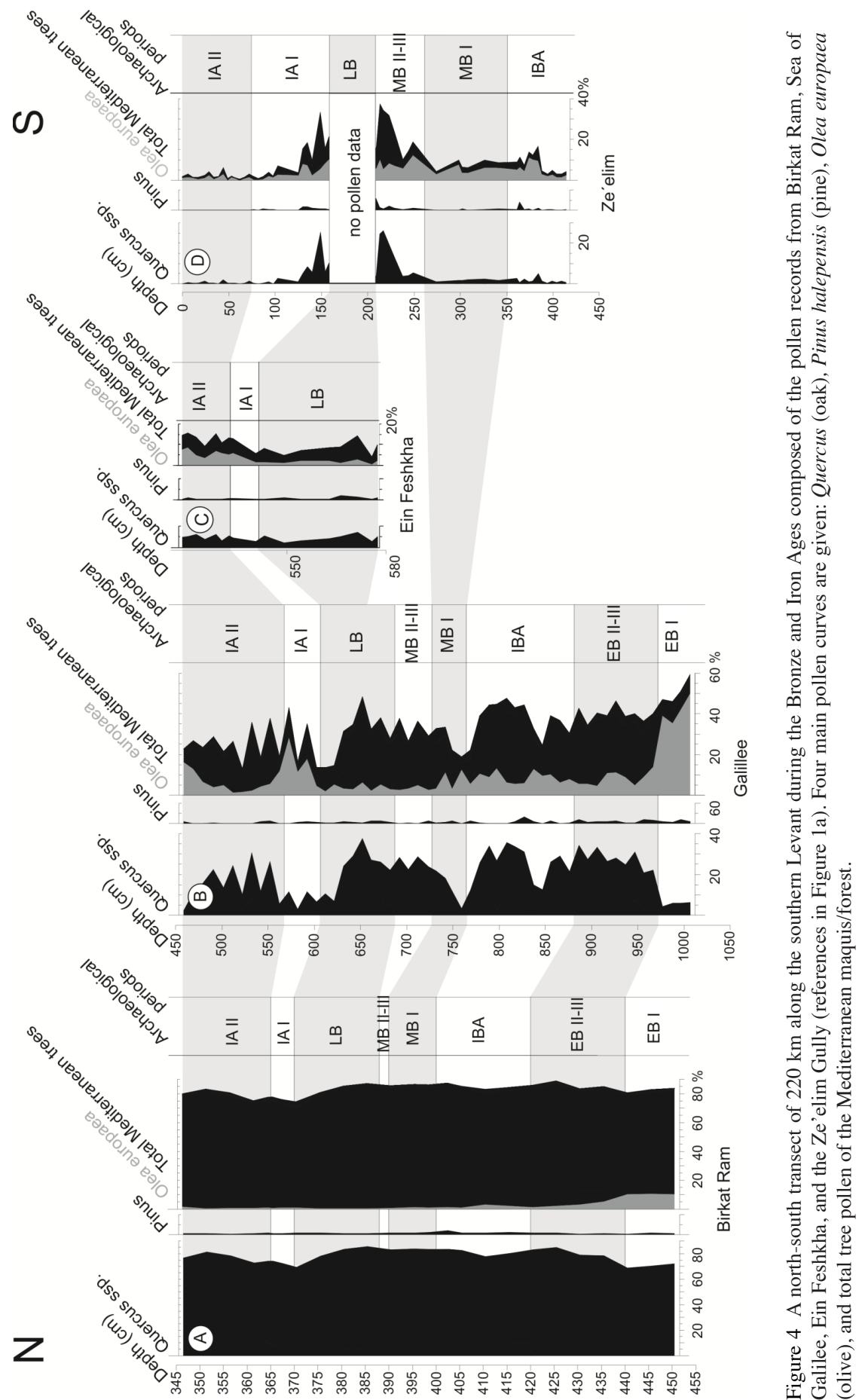

(various articles in van den Brink and Levy 2002). Secondary products of the highlands' olive horticulture activity must have played a major role in this network (e.g. Finkelstein and Gophna 1993; van den Brink and Braun 2002). 
The highest olive frequencies characterizing the Early Bronze Age I were followed by a dramatic decline in olive pollen percentages during the transition to the Early Bronze Age II, as evident in both pollen records (Figures 4a,b), although this decrease is much more pronounced at the Sea of Galilee, where it is accompanied by strong increase of deciduous oak (the Quercus ithaburensis type; Figure 3). In the Early Bronze Age II-III ( 3000-2500 BCE), a minor increase in oak pollen was also documented in the Birkat Ram record, signaling a slight spread of the natural Mediterranean forest/maquis (Figure 4a). Since the decreasing olive percentages were not accompanied by a reduction of arboreal pollen, this decline in olive pollen was probably linked to changes in geopolitical (rather than climatic) conditions in the region. We refer to the weakening of overland connections with Egypt and the rise of maritime links with the coast of present-day Lebanon (Marcus 2002), which may indicate that the main area of export of olive oil to Egypt shifted to the north. The relatively humid period characterizing the Early Bronze Age II-III saw the rise of important urban centers in the southern Levant (e.g. Tel Bet Yerah in the north and Tel Yarmuth in the south).

\section{Intermediate Bronze Age ( 2500-1950 BCE)}

At both Birkat Ram and the Sea of Galilee, this period shows no major change in the distribution of the Mediterranean arboreal vegetation in comparison to the previous period (Figures 4a,b). Therefore, it seems that the crisis in the urban system, which started at the end of the Early Bronze Age ( 2500 BCE, Regev et al. 2012) and lasted through the entire Intermediate Bronze Age, was not a result of climate change. Yet, during this relatively climatically stable period, two short events pointing to drier conditions were recorded: at $2350 \mathrm{BCE}$ (based on the Sea of Galilee record) and at the end of the Intermediate Bronze/beginning of the Middle Bronze Age I (the Sea of Galilee and Ze'elim; Figures 4b,d). These dry events were also documented by the declining level of the Dead Sea (Kagan et al. 2015). The Intermediate Bronze Age features evidence for strong settlement activity in the Negev Highlands (Cohen 1999); the latter dry event may be one of the reasons for the decline of this settlement system.

The Intermediate Bronze Age is a period traditionally associated with a more pastoral mode of subsistence in the southern Levant. However, the northern pollen records (Birkat Ram and the Sea of Galilee) show that no major shift took place in human exploitation of the environment; that is, olives were still probably cultivated to the same extent as during the previous period, the Early Bronze Age II-III. Since Olea pollen production has a strong response to cessation (a dramatic decrease in pollen production was documented in deserted orchards after several decades of abandonment; Langgut et al. 2014b), the olive pollen that was identified during the Intermediate Bronze Age represents well-maintained orchards.

In the southern record of Ze'elim, an olive pollen peak of maximally $10 \%$ of the total pollen was identified around the second part of the Intermediate Bronze Age ( 2200-2000 BCE), which probably indicates expansion of olive horticulture in the southern Judean Highlands (Figure 4d). A pronounced rise in Olea pollen percentages was also documented around the same time in the Ein Gedi core (13 km north of Ze'elim; Litt et al. 2012). We suggest that the high distribution of olive probably reflects human influence in the Judean Highlands rather than increased precipitation, since this Olea peak was not accompanied by any significant rise in other Mediterranean trees. Settlement activity in the Judean Highlands in the Intermediate Bronze Age was limited (Ofer 1994), so the pollen record may attest to possible transhumance links between the Negev Highlands and Hebron Hills (e.g. Dever 1980), that is, to pastoral groups that moved between winter and summer camps and engaged in opportunistic horticulture in the wetter southern Highlands.

In addition to the drier climate conditions that were prevalent at the end of the period based on 
the decline in the Mediterranean trees, a slight decrease of Olea pollen and somewhat increase in pine values were identified in two out of the three pollen diagrams available for this period: Birkat Ram and Ze'elim (Figures 4a,d). In historical periods, pine was the first tree of the Mediterranean maquis/forest that established itself naturally in large numbers in disturbed areas (Baruch 1986, 1990; Lev-Yadun and Weinstein-Evron 2002). We therefore suggest that some olive orchards were abandoned at the end of this period in certain parts of the southern Levant (probably not in the Sea of Galilee area).

More arid conditions at the end of the Intermediate Bronze Age are also evident by the lithology of the Ze'elim section, which points to accumulation of sediments in a shore environment (sands and a thin beach ridge were deposited from 2000 to $\sim 1800$ BCE) (Langgut et al. 2014a; Kagan et al. 2015). Drier climate conditions were also documented by (A) the declining level of the Dead Sea (from 380 to $400 \mathrm{~m}$ bsl; yet, the drop began slightly earlier 2200/2100 BCE and lasted about 200-300 yr) (Migowski et al. 2006; Kagan et al. 2015) and (B) the isotopic composition of tamarisk wood from the Mount Sedom Cave (southern Dead Sea), which also points to a prolonged drought (of $>100 \mathrm{yr}$ ) at the end of the Intermediate Bronze Age (Frumkin 2009). The Soreq Cave speleothems isotopic record also points to a decrease in precipitation during 2200-1900 BCE (BarMatthews and Ayalon 2004, 2011).

\section{Middle Bronze Age ( 1950-1550 BCE)}

From the beginning of the period and until about 1800 BCE, Mediterranean tree values remain low, as evidenced by the more "climate-sensitive" pollen records - the Sea of Galilee and Ze'elim — while Birkat Ram does not point to any pronounced climate change. It therefore seems that the dry period that began at the end of the Intermediate Bronze Age lasted about 2 centuries ( 2000-1800 BCE). In the Ein Gedi pollen diagram, a reduction in Mediterranean elements was documented in the same time interval, pointing to a decrease in humidity (Litt et al. 2012). During the Middle Bronze Age I, in both records (Sea of Galilee and Ze'elim), olive tree percentages appear in the same magnitude as in the Intermediate Bronze Age, representing olive production probably only for local consumption.

The wetter climate conditions, which were recognized by the increasing percentages in Mediterranean trees around $1800 \mathrm{BCE}$, continued through the Middle Bronze Age II-III and probably led to re-expansion of the Mediterranean maquis/forest in the region; note, for example, in the Sea of Galilee record (Figure 3) the maximum pollen percentages of evergreen oak and Pistacia towards the end of the Middle Bronze Age, which may point to a well-developed Quercus calliprinos-Pistacia palaestina association in the Mediterranean maquis/forest.

Evidence for dry climate conditions in the beginning of Middle Bronze Age and more humid conditions in the later phases is also provided by the lithology of the Ze'elim record, which points to the accumulation of sediments in a shore environment (sands and beach ridge) during the Middle Bronze Age I, and therefore indicates relatively low Dead Sea stands. During the Middle Bronze Age II-III, sediments accumulated in a lacustrine environment (mainly detritus), representing an increase in Dead Sea levels (Langgut et al. 2014a; Kagan et al. 2015). Indeed, according to the reconstruction of the Dead Sea levels, during the Middle Bronze Age II-III, the lake reached its highest level in the last 4 millennia - up to $370 \mathrm{~m}$ bsl (Migowski et al. 2006; Kushnir and Stein 2010). These paleoclimate data (sedimentological and Dead Sea levels reconstruction) are also indicators of high moisture in the northern parts of the Dead Sea drainage basin (Figure 2). They also confirm the palynological observation of regional dryness (rather than human-induced changes) during the Middle Bronze Age I. 
The archaeological finds indicate that the low settlement activity at the end of the Intermediate Bronze Age continued in the Judean Highlands into the Middle Bronze Age I, before an increased presence in the Middle Bronze Age II-III (Ofer 1994; Finkelstein 1995). The dry phase in the very late Intermediate Bronze Age and the Middle Bronze Age I had significant impact on settlement patterns in the entire Levantine region. During that time, the 400-mm rainfall isohyet, marking the boundary between the Mediterranean and Irano-Turanian vegetation zones, seems to have shifted to the north and west. As a result, permanent settlements withdrew from the southern margins of southern Canaan and population in northeastern semi-arid zones, such as the Beq'a of Lebanon and the Jezirah in Syria, shrank in size (Finkelstein and Langgut 2014). For this reason, significant numbers of people may have moved to "greener" parts of the Levant. Wetter conditions in the Middle Bronze Age II-III ( 1750-1550 BCE) caused the settlement system to recover and re-expand in the south (in areas such as the Beer Sheba Valley in the northern Negev).

\section{Late Bronze Age ( 1550-1150 BCE)}

According to the northern pollen diagrams (Birkat Ram and Sea of Galilee; Figures 4a,b) during the beginning of the period, the Mediterranean arboreal vegetation values remain relatively high, representing the continuity of a well-developed Mediterranean forest/maquis. Indeed, very high percentages of evergreen oak (Quercus calliprinos type) and Pistacia characterize this time interval in the Sea of Galilee diagram (Figure 3). The Ein Feshkha record begins in the middle of the Late Bronze Age; it features high arboreal percentages, which decrease towards the end of the period, signaling drier climate conditions (Figure 4c). No pollen data for the Late Bronze Age are available from the Ze'elim record (Figure 4d) due to some sedimentary erosion and unfavorable conditions for pollen preservation in sandy sediments (Langgut et al. 2014a).

During the 14th century BCE, high frequencies of total Mediterranean pollen trees were recorded in the Sea of Galilee pollen diagram, most probably indicating relatively wet climate conditions (Figures 3 and 4b); this is consistent with the fact that the Amarna tablets, dated to 1360-1330/35 BCE, do not mention droughts or famine in the Levant. Yet, the values of olive pollen remain in their low frequencies, indicating a limited spread of olive horticulture (Figures $4 \mathrm{a}-\mathrm{c}$ ). The Ein Gedi palynological record (Litt et al. 2012) is consistent with this picture.

The Late Bronze Age was marked with a dramatic decrease in the settlement activity in the hill country of the Galilee, Samaria, and Judea (Bunimovitz 1994; Ofer 1994; Finkelstein 1995). The relatively high frequencies of the arboreal pollen indicate that in much of the period the settlement crisis was human-induced rather than a result of environmental change.

Yet, according to all four pollen records, the most striking feature in the Bronze and Iron Age pollen transect appeared at the end of the Late Bronze Age. This phase is characterized by extremely low arboreal vegetation percentages (both Mediterranean trees and olive trees) in the Sea of Galilee and Ein Feshkha, while in the less-sensitive Birkat Ram record only a slight reduction in arboreal pollen was documented. Based on the Ein Gedi (Litt et al. 2012) and Sea of Galilee pollen records, it is assumed that the decline in Mediterranean elements began during the mid-13th century BCE. However, it seems that in the former record the dry event lasted longer (down to the early stage of the Iron Age I), while according to the Sea of Galilee, the arid event occurred from the mid-13th century BCE until the end of the 12th century BCE. The dramatic drop in the reconstructed Dead Sea levels (from 370 to $418 \mathrm{~m}$ bsl) was dated slightly earlier, to $1400-1200$ BCE (Kagan et al. 2015). Litt et al. (2012) also report that around 1300 BCE a thick sand unit accumulated in the Ein Gedi core and Neumann et al. (2007a) describe a sedimentological unconformity in the Ein Feshkha record about the same time. At the Ze'elim Gully, a beach ridge was deposited in a shore environment around 
1200 BCE (Langgut et al. 2014a; Kagan et al. 2015). The occurrence of a shore depositional environment in these western Dead Sea margin sites (Ein Gedi, Ein Feshkha, Ze'elim) represents a drop in the Dead Sea lake levels that was most probably the result of reduced precipitation at the end of the Late Bronze Age, mainly in the area of the northern sources of the Dead Sea drainage basin.

It is noteworthy that the decrease in tree percentages was not accompanied by an increase of secondary anthropogenic palynological indicators (e.g. Plantago lanceolata [ribwort plantain] pollen type-Baruch 1990; Danin 2004) in the Birkat Ram (Neumann et al. 2007b), Sea of Galilee (Figure 3), or Ein Feshkha records (Neumann et al. 2007a); therefore, the decline in the arboreal vegetation was probably not as a result of deforestation. In the Sea of Galilee record, a dramatic reduction in evergreen oak and Pistacia percentages was documented, with almost total disappearance of other Mediterranean trees such as Phillyrea and with an increase in of the semi-desert and desert plants Chenopodiaceae and Artemisia (Figure 3). Because of low settlement activity at that time, shrinkage of the Mediterranean forest was most probably not the result of human pressure. The decline in arboreal percentages was therefore a result of climate rather than human-induced change; this is also supported by the sedimentology and configuration of the Dead Sea as described earlier.

A dry event during the end of the Late Bronze Age and into the transition to the Iron Age I was detected in three other high-resolution pollen records from the Levant: the northern Syrian coast (Kaniewski et al. 2010), Cyprus (Kaniewski et al. 2013), and the Nile Delta (Bernhardt et al. 2012). These data suggest that the dry spell at the end of the Late Bronze Age took place across a vast geographical area.

Harsh, long-term droughts may be the prime mover, then, for the sociopolitical collapse in the eastern Mediterranean basin during the "crisis years" at the end of the Bronze Age (Carpenter 1966; Weiss 1982; Neumann and Parpola 1987; Alpert and Neumann 1989; Ward and Joukowsky 1992; Issar 1998). Archaeological evidence indicates that the crisis in the eastern Mediterranean took place from the mid-13th century to the end of the 12th century BCE-during the same time interval when drier climate conditions were prevalent in the region. In the Levant, the crisis years are represented by destruction of urban centers, shrinkage of other major sites, hoarding activities, and changes in settlement patterns. Textual evidence from several places in the Ancient Near East attests to drought and famine starting in the mid-13th century BCE and continuing until the second half of the 12th century BCE (Astour 1965; Klengel 1974:170-4; Na'aman 1994:243-5; Zaccagnini 1995; Singer 1999:715-9, 2000, 2009:99).

\section{Iron Age I ( 1150-950 BCE)}

All four pollen records for the Iron Age I time interval display a rise in oaks, total Mediterranean trees, and olive pollen percentages. In Birkat Ram, where only two samples fall within the Iron Age I, a minor peak of Mediterranean trees is visible at the transition from the Late Bronze Age to the Iron Age I (Figure 4a). In the Sea of Galilee, a pronounced Olea peak is notable; a similar peak appears in the Ein Feshkha and Ze'elim records together with an increase in oak pollen (Figures $4 \mathrm{~b}, \mathrm{~d})$. Thanks to the increase in available moisture following the severe dryness at the end of the Late Bronze Age, both the Mediterranean forest/maquis and olive orchards expanded. This is evident also in the Ein Gedi pollen record starting at 1000 BCE (Litt et al. 2012) and by the moderate rise in the Dead Sea level (Migowski et al. 2006; Stein et al. 2010). The improved climate conditions during the Iron I enabled the recovery of settlement activity. This is evident in the revival of the urban system in the northern valleys (Finkelstein 2003) and in the settlement wave in the highlands, including areas that are amenable to olive orchards (Gal 1992; Finkelstein 1995; Frankel et al. 2001; Zertal 2004, 2007). Evidence for better water availability for plants was also found by 
Riehl (2009) as well as archaeobotanical indications for an increase in olive cultivation during this period (Liphschitz 2007; Riehl 2009:Figure 7).

The growth of settlement activity in the highlands is the backdrop for the rise of Ancient Israel and other Iron I Age groups- the Arameans, Ammon, and Moab (Finkelstein 1995; Joffe 2002). Especially noteworthy are settlement developments on the margin of the settled lands: the spread of activity in the Beer Sheba Valley (Herzog 1994), the rise of an early Moabite territorial polity south of the Arnon River (Finkelstein and Lipschits 2011), and the appearance of Iron Age I sites on the Edomite plateau (Finkelstein 1992).

\section{Iron Age II ( 950-586 BCE)}

In the Iron Age IIA ( 950-780 BCE), Mediterranean trees retain their values, representing a developed Mediterranean forest/maquis and relatively humid climate conditions, while the Iron Age IIB ( 780-680 BCE) and the Iron Age IIC (680-586 BCE) are characterized by a slight decrease in Mediterranean trees as evident in all three northern pollen records (Birkat Ram, Sea of Galilee, and Ein Feshkha). The slight reduction in arboreal percentages may represent moderate climate conditions but could also result from anthropogenic activity such as tree clearing for building purposes and spread of agriculture and grazing activities. Indeed, a surge in human activity that had started in the Iron Age I and increased in the late Iron IIA reached its zenith during the Iron Age IIB-C (e.g. Ofer 1994 for the Judean Highlands).

The picture is less clear in the southernmost record (Ze'elim), where Mediterranean arboreal pollen appears in relatively low values starting with the end of the Iron Age I and through the entire period of the Iron Age II, while the lithology of this sequence shows that at that time the sediments were deposited in a lake environment, and therefore represent relatively high Dead Sea lake levels ( $\sim 408 \mathrm{~m}$ bsl). The reconstructed Dead Sea levels for this period indicate moderate climate conditions [the level still stood beneath the sill separating the northern and southern basins of the Dead Sea; Bookman (Ken-Tor) et al. 2004; Migowski et al. 2006; Kushnir and Stein 2010; Kagan et al. 2015].

\section{CONCLUSIONS}

This paper presents the role of climate fluctuations in shaping southern Levantine human history 3600-600 BCE (the Bronze and Iron Ages) as evidenced in four palynological archives. Three out of the four pollen records presented in this study show similar vegetation fluctuations (Sea of Galilee, Ein Feshkha, and Ze'elim), indicating that at least in the Bronze and Iron Ages different regions of the southern Levant were characterized by similar climate patterns. Most vegetation changes presented in this study occurred in the Mediterranean and semi-arid vegetation zones. The Birkat Ram record does not point to any dramatic vegetation and climate fluctuations because of its northern location within an area that receives more than $1000 \mathrm{~mm}$ of annual rainfall, which makes it a less sensitive climate recorder.

The climate history of the southern Levant during the Bronze and Iron Ages, derived from the high-resolution pollen diagrams, can be summarized as follows (Figure 5): The wettest period was identified during the Early Bronze Age I ( 3600-3000 BCE). Though a reduction in the arboreal pollen percentages was documented during the Early Bronze Age II-III ( $\sim 3000-2500 \mathrm{BCE})$, the region was still typified by humid climate conditions. The Intermediate Bronze Age ( 2500-1950 BCE) was characterized by moderate climate conditions. Since $\sim 2000$ BCE and during the Middle Bronze Age I ( 1950-1750 BCE), drier climate conditions were prevalent, while the Middle Bronze Age II-III ( 1750-1550 BCE) was somewhat wetter. During the early phases of the Late Bronze Age, humid conditions continued. The driest conditions in the entire Bronze and Iron Age timespan were 


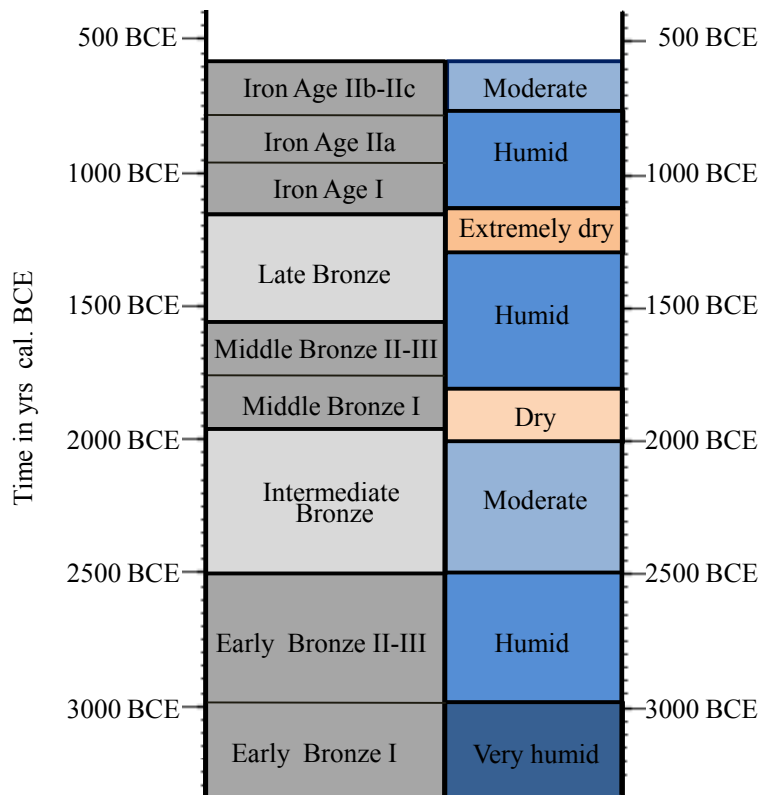

Figure 5 Summary of the climate history of the southern Levant during the Bronze and Iron Ages based on the palynological evidence.

recorded towards the end of this period and down to the end of the 12th century BCE. An increase in arboreal percentages was documented between $\sim 1100-750$ BCE, which therefore covers most of the Iron Age I ( 1150-950 BCE) and the Iron Age IIA ( $\sim 950-780 \mathrm{BCE})$, representing humid conditions after the severe dryness. During the Iron Age IIB ( 780-680 BCE) and IIC ( 680-586 BCE), the region experienced moderate climate.

Two relatively profoundly dry periods were identified based on the significant decrease in oaks and the total Mediterranean arboreal pollen. The first dry episode was dated to 2000-1800 BCE and resulted in the shift of the border between the Mediterranean and Irano-Turanian vegetation zones to the north and west. Permanent settlements withdrew from the southern margins of southern Canaan. The second, more severe event occurred at the end of the Late Bronze Age and lasted until the end of the 12th century BCE. This arid phase, characterized by the lowest arboreal percentages in the Bronze and Iron Ages, probably represents long and severe droughts. The dry climate conditions at the end of the Late Bronze Age seem to correspond to references in Ancient Near Eastern texts to a period of droughts and famine and thus political instability, which is also reflected in the archaeological record (destruction of cities, etc.). All this helps to better understand the "crisis years" in the eastern Mediterranean at the end of the Bronze Age.

\section{ACKNOWLEDGMENTS}

This study was funded by the European Research Council under the European Community's Seventh Framework Program (FP7/2007-2013)/ERC grant agreement no. 229418. We wish to thank M Kitin, I Ben-Ezra, and M Pollak for their technical help and to the team from the Bonn Palynological Laboratory for recovering the Sea of Galilee core and for pollen samples preparation.

\section{REFERENCES}

Al-Eisawi D. 1996. Vegetation of Jordan. Cairo: Regional Office for Science and Technology for the Arab States.

Alpert P, Neumann J. 1989. An ancient "correlation" between streamflow and distant rainfall in the Near
East. Journal of Near Eastern Studies 48:313-4. Astour MC. 1965. New evidence on the last days of Ugarit. American Journal of Archaeology 69(3):253-8. Bar-Matthews M, Ayalon A. 2004. Speleothems as palaeoclimate indicators, a case study from Soreq 
Cave located in the Eastern Mediterranean Region, Israel. In: Battarbee RW, Stickley CE, editors. Past Climate Variability through Europe and Africa. Dordrecht: Springer. p 363-91.

Bar-Matthews M, Ayalon A. 2011. Mid-Holocene climate variations revealed by high-resolution speleothem records from Soreq Cave, Israel and their correlation with cultural changes. The Holocene 21(1):163-71.

Baruch U. 1986. The Late Holocene vegetational history of Lake Kinneret (Sea of Galilee), Israel. Paléorient 12(2):37-48

Baruch U. 1990. Palynogical evidence of human impact on the vegetation as recorded in Late Holocene lake sediments in Israel. In: Bottema S, Entjes-Nieborg G, van Zeist W, editors. Man's Role in the Shaping of the Eastern Mediterranean Landscape. Rotterdam: Balkema. p 283-93.

Baruch U. 1993. The palynology of Late Quaternary sediments of the Dead Sea [unpublished PhD dissertation]. Jerusalem: Hebrew University of Jerusalem. In Hebrew with English abstract.

Baruch U, Bottema S. 1999. A new pollen diagram from Lake Hula: vegetational, climatic and anthropogenic implications. In: Kawanabe H, Coulter GW, Roosevelt AC, editors. Ancient Lakes: Their Cultural and Biological Diversity. Ghent: Kenobi Production. p 75-86.

Bernhardt CE, Horton BP, Stanley JD. 2012. Nile Delta vegetation response to Holocene climate variability. Geology 40(7):615-8.

Bietak M. 2002. Relative and absolute chronology of the Middle Bronze Age: comments on the present state of research. In: Bietak M, editor. The Middle Bronze Age in the Levant: Proceedings of an International Conference on MBIIA Ceramic Material. Vienna 24th of January-28th of January 2001. Vienna: Verlag der Osterreichischen Akademie der Wissenschaften. p 29-42.

Bookman (Ken-Tor) R, Enzel Y, Agnon A, Stein M. 2004 Late Holocene lake levels of the Dead Sea. Geological Society of America Bulletin 116(5-6):555-71.

Bryant VM. 1989. Pollen: nature's fingerprints of plants. Yearbook of Science and the Future. Chicago: Encyclopedia Britannica. p 92-111.

Bunimovitz S. 1994. The problem of human resources in Late Bronze Age Palestine and its socioeconomic implications. Ugarit-Forschungen 26:1-20.

Cappers R, Bottema S, Woldring H. 1998. Problems in correlating pollen diagrams of the Near East: a preliminary report. In: Damania AB, Valkoun J, Willcox G, Qualset CO, editors. The Origins of Agriculture and Crop Domestication, International Center for Agricultural Research in Dry Areas. Aleppo: ICARDA. p 160-9.

Carpenter R. 1966. Discontinuity in Greek Civilization. Cambridge: Cambridge University Press.

Cohen R. 1999. Ancient Settlement of the Central Negev. Jerusalem: Israel Antiquities Authority.

Danin A. 2004. Distribution Atlas of Plants in the Flora
Palaestina Area. Jerusalem: Israel Academy of Sciences and Humanities.

Dayan U, Ziv B, Shoob T, Enzel Y. 2007. Suspended dust over southeastern Mediterranean and its relation to atmospheric circulations. International Journal of Climatology 28(7):915-24.

Dever WG. 1980. New vistas on EB IV (“MBI") horizon in Syria-Palestine. Bulletin of American Schools of Oriental Research 237:35-64.

Eastwood WJ, Roberts N, Lamb HF. 1998. Palaeoecological and archaeological evidence for human occupancy in southwest Turkey: the Beysehir occupation phase. Anatolian Studies 48:69-86.

Eitam D. 1993. "Between the [olive] rows, oil will be produced, presses will be trod..." (Job 24, 11). In: Amouretti MC, Brun JP, editors. Oil and Wine Production in the Mediterranean Area. Athens: Bulletin de Correspondance Hellenidue, Supplement XXVI. p 65-90.

Epstein C. 1978. A new aspect of Chalcolithic culture. Bulletin of the American Schools of Oriental Research 229:27-45.

Epstein C. 1993. Oil production in the Golan Heights during the Chalcolithic period. Tel Aviv 20:133-46.

Epstein C. 1998. The Chalcolithic Culture of the Golan. Jerusalem: Israel Antiquities Authority.

Faegri K, Iversen J. 1989. Textbook of Pollen Analysis. 4th edition. New York: John Wiley \& Sons.

Finkelstein I. 1992. Edom in the Iron I. Levant 24:15966.

Finkelstein I. 1995. The great transformation: the "conquest" of the highlands frontiers and the rise of the territorial states. In: Levy TE, editor. The Archaeology of Society in the Holy Land. London: Leicester University Press. p 349-65.

Finkelstein I. 2003. City-states to states: polity dynamics in the 10th-9th centuries BCE. In: Dever WG, Gitin S, editors. Symbiosis, Symbolism and the Power of the Past: Canaan, Ancient Israel, and Their Neighbors from the Late Bronze Age through Roman Palaestina. Proceedings of the Centennial Symposium, W. F. Albright Institute of Archaeological Research, Jerusalem, May 29-31, 2000. Winona Lake: Eisenbrauns. p 75-84.

Finkelstein I, Gophna R. 1993. Settlement, demographic, and economic patterns in the highlands of Palestine in the Chalcolithic and Early Bronze periods and the beginning of urbanism. Bulletin of the American Schools of Oriental Research 289:1-22.

Finkelstein I, Langgut D. 2014. Dry climate in the Middle Bronze I and its impact on settlement patterns in the Levant and beyond: new pollen evidence. Journal of Near Eastern Studies 73(2):219-34.

Finkelstein I, Lipschits O. 2011. The genesis of Moab: a proposal. Levant 43:139-52.

Finkelstein I, Piasetzky E. 2010. Radiocarbon dating the Iron Age in the Levant: a Bayesian model for six ceramic phases and six transitions. Antiquity 84(324):374-85.

Finkelstein I, Halpern B, Lehmann G, Niemann HM. 
2006. The Megiddo hinterland project. In: Finkelstein I, Ussishkin D, Halpern B, editors. Megiddo IV: The 1998-2002 Seasons. Tel Aviv: Institute of Archaeology. p 705-76.

Frankel R, Getzov N, Aviam M, Degani A. 2001. Settlement Dynamics and Regional Diversity in Ancient Upper Galilee. Jerusalem: IAA Reports 14.

Frumkin A. 2009. Stable isotopes of a subfossil Tamarix tree from the Dead Sea region, Israel, and their implications for the Intermediate Bronze Age environmental crisis. Quaternary Research 71(3):319-28.

Gal Z. 1992. Lower Galilee during the Iron Age. Winona Lake: Eisenbrauns.

Gophna R, Kislev M. 1979. Tel Saf (1977-1978). Revue Biblique 86:112-4.

Hazan N, Stein M, Agnon A, Marco S, Nadel D, Negendank J, Schwab M, Neev D. 2005. The late Quaternary limnological history of Lake Kinneret (Sea of Galilee), Israel. Quaternary Research 63(1):60-77.

Herzog Z. 1994. The Beer-Sheba valley: from nomadism to monarchy. In: Finkelstein I, Na'aman N, editors. From Nomadism to Monarchy: Archaeological and Historical Aspects of Early Israel. Jerusalem: Israel Exploration Society. p 122-49.

Horowitz A. 1979. The Quaternary of Israel. New York: Academic Press.

Issar A. 1998. Climate change and history during the Holocene in the eastern Mediterranean region. In: Issar A, Brown N, editors. Water, Environment and Society in Times of Climate Change. Dordrecht: Kluwer Academic. p 113-28.

Joffe AH. 2002. The rise of secondary states in the Iron Age Levant. Journal of the Economic and Social History of the Orient 45:425-67.

Kadosh D, Sivan D, Kutiel H, Weinstein-Evron M. 2004. A late Quaternary paleoenvironmental sequence from Dor, Carmel coastal plain, Israel. Palynology 28:143-57.

Kagan E, Stein M, Agnon A, Neumann F. 2011. Intrabasin paleoearthquake and quiescence correlation of the Late Holocene Dead Sea. Journal of Geophysical Research 116:B04311.

Kagan E, Langgut D, Boaretto E, Neumann FH, Stein M. 2015. Dead Sea levels during the Bronze and Iron Ages. Radiocarbon 57(2):237-52. (this issue)

Kaniewski D, Paulissen E, Van Campo E, Weiss H, Otto T, Bretschneider J, Van Lerberghe K. 2010. Late second-early first millennium BC abrupt climate changes in coastal Syria and their possible significance for the history of the Eastern Mediterranean. Quaternary Research 74(2):207-15.

Kaniewski D, van Campo E, Guiot J, Le Burel S, Otto T, Baeteman C. 2013. Environmental roots of the Late Bronze Age crisis. PLoS ONE 8:e71004.

Ken-Tor R, Agnon A, Enzel Y, Stein M, Marco S, Negendank JFW. 2001. High-resolution geological record of historic earthquakes in the Dead Sea basin. Journal of Geophysical Research: Solid Earth 106(B2):2221-34.

Klengel H. 1974. Hungerjahre' in Hatti. Altorientalische
Forschungen 1:165-74.

Kushnir Y, Stein M. 2010. North Atlantic influence on 19th-20th century rainfall in the Dead Sea watershed, teleconnections with the Sahel, and implication for Holocene climate fluctuations. Quaternary Science Reviews 29(27-28):3843-60.

Lamb AL, Leng MJ, Lamb HF, Mohammed MU. 2000. A 9000-year oxygen and carbon isotope record of hydrological change in a small Ethiopian crater lake. The Holocene 10(2):167-77.

Lamb HF. 2001. Multi-proxy records of Holocene climate and vegetation change from Ethiopian crater lakes. Biology and Environment Proceedings of the Royal Irish Academy 101B(1-2):35-46.

Langgut D, Almogi-Labin A, Bar-Matthews M, Weinstein-Evron M. 2011. Vegetation and climate changes in the south eastern Mediterranean during the Last Glacial-Interglacial cycle (86 ka): new marine pollen record. Quaternary Science Reviews 30(2728):3960-72.

Langgut D, Finkelstein I, Litt T. 2013. Climate and the Late Bronze collapse: new evidence from the southern Levant. Tel Aviv 40(2):149-75.

Langgut D, Neumann FH, Stein M, Wagner A, Kagan EJ, Boaretto E, Finkelstein I. 2014a. Dead Sea pollen record and history of human activity in the Judean Highlands (Israel) from the Intermediate Bronze into the Iron Ages ( 2500-500 BCE). Palynology 38(2):280-302.

Langgut D, Lev-Yadun S, Finkelstein I. 2014b. The impact of olive orchard abandonment and rehabilitation on pollen signature: an experimental approach to evaluating fossil pollen data. Ethnoarchaeology 6(2): 121-35

Lev-Yadun S, Weinstein-Evron M. 2002. The role of Pinus halepensis (Aleppo pine) in the landscape of Early Bronze Age Megiddo. Tel Aviv 29:332-43.

Liphschitz N. 2007. Timber in Ancient Israel: Dendroarchaeology and Dendrochronology. Tel Aviv: Institute of Archaeology.

Litt T, Ohlwein C, Neumann FH, Hense A, Stein M. 2012. Holocene climate variability in the Levant from the Dead Sea pollen record. Quaternary Science Reviews 49:95-105.

Marcus E. 2002. Early seafaring and maritime activity in the southern Levant from prehistory through the third millennium BCE. In: van den Brink ECM, Levy TE, editors. Egypt and the Levant: Interrelations from the 4th through Early 3rd millennium $B C E$. London: Leicester University. p 403-17.

Meadows J. 2005. The Younger Dryas episode and the radiocarbon chronologies of the Lake Huleh and Ghab Valley pollen diagrams, Israel and Syria. The Holocene 15(4):631-6.

Migowski C, Stein M, Prasad S, Negendank JFW, Agnon A. 2006. Holocene climate variability and cultural evolution in the Near East from the Dead Sea sedimentary record. Quaternary Research 66(3):421-31

Na'aman N. 1994. The 'Conquest of Canaan' in the Book 
of Joshua and in history. In: Finkelstein I, Na'aman N, editors. From Nomadism to Monarchy: Archaeological and Historical Aspects of Early Israel. Jerusalem: Israel Exploration Society. p 218-81.

Neef R. 1990. Introduction, development and environ mental implications of olive culture: the evidence from Jordan. In: Bottema S, Entjes-Nieborg G, Zeist WV, editors. Man's Role in the Shaping of the Eastern Mediterranean Landscape. Rotterdam: A.A. Balkema. p 295-306.

Neev D, Emery KO. 1995. The Destruction of Sodom, Gomorrah, and Jericho. Geological, Climatological, and Archaeological Background. New York: Oxford University Press.

Neumann J, Parpola S. 1987. Climatic change and the eleventh-tenth-century eclipse of Assyria and Babylonia. Journal of Near Eastern Studies 46(3):16182.

Neumann FH, Kagan EJ, Schwab MJ, Stein M. 2007a. Palynology, sedimentology and palaeoecology of the Late Holocene Dead Sea. Quaternary Science Reviews 26(11-12):1476-98.

Neumann F, Schölzel C, Litt T, Hense A, Stein M. $2007 \mathrm{~b}$. Holocene vegetation and climate history of the northern Golan Heights (Near East). Vegetation History and Archaeobotany 16(4):329-46.

Neumann FH, Kagan EJ, Stein M, Agnon A. 2009. Assessment of the effect of earthquake activity on regional vegetation-high-resolution pollen study of the Ein Feshka section, Holocene Dead Sea. Review of Palaeobotany and Palynology 155(1-2):42-51.

Neumann F, Kagan E, Leroy S, Baruch U. 2010. Vegetation history and climate fluctuations on a transect along the Dead Sea west shore and their impact on past societies over the last 3500 years. Journal of Arid Environments 74(7):756-64.

Ofer A. 1994. 'All the hill country of Judah': from a settlement fringe to a prosperous monarchy. In: Finkelstein I, Na'aman N, editors. From Nomadism to Monarchy: Archaeological and Historical Aspects of Early Israel. Jerusalem: Israel Exploration Society. p 92-121.

Rambeau CM. 2010. Palaeoenvironmental reconstruction in the southern Levant: synthesis, challenges, recent developments and perspectives. Philosophical Transactions of the Royal Society 368:5225-48.

Regev J, de Miroschedji P, Greenberg R, Braun E, Greenhut Z, Boaretto E. 2012. Chronology of the Early Bronze Age in the southern Levant: new analysis for a high chronology. Radiocarbon 54(3-4):525-66.

Riehl S. 2009. Archaeobotanical evidence for the interrelationship of agricultural decision-making and climate change in the ancient Near East. Quaternary International 197(1-2):93-114.

Schiebel V. 2013. Environmental response on climate impact in the Levant during the Last Glacial and Holocene and their role in the origin of agriculture [unpublished $\mathrm{PhD}$ dissertation]. Bonn: Bonn University.

Schwab MJ, Neumann F, Litt T, Negendank JF, Stein M.
2004. Holocene palaeoecology of the Golan Heights (Near East): investigation of lacustrine sediments from Birkat Ram crater lake. Quaternary Science Reviews 23(16-17):1723-31.

Shmida A, Or Y. 1983. The Sudanian flora in Israel: introduction. Rotem 8:4-10. In Hebrew.

Singer A, Ehrlich A. 1978. Paleolimnology of a Late Pleistocene-Holocene crater lake from the Golan Heights, eastern Mediterranean. Journal of Sedimentary Research 48(4):1331-40.

Singer I. 1999. A political history of Ugarit. In: Watson GEW, Wyatt N, editors. Handbook of Ugaritic Studies. Leiden: Brill. p 603-733.

Singer I. 2000. New evidence on the end of the Hittite empire. In: Oren ED, editor. The Sea Peoples and Their World: A Reassessment. Philadelphia: University of Pennsylvania Press. p 21-34.

Singer I. 2009. The Hittites and Their Civilization. Jerusalem: Bialik Institute. In Hebrew.

Sivak J. 1975. Les caractères de diagnose de grains de pollen a ballonets. Pollen et Spores 17:349-421.

Srebro H, Soffer T. 2011. The New Atlas of Israel: The National Atlas. Jerusalem: Survey of Israel and The Hebrew University of Jerusalem.

Stein M. 2001. The sedimentary and geochemical record of Neogene-Quaternary water bodies in the Dead Sea Basin - inferences for the regional paleoclimatic history. Journal of Paleolimnology 26(3):271-82.

Stein M. 2014a. The evolution of Neogene-Quaternary water-bodies in the Dead Sea rift valley. In: Garfunkel Z, Ben-Avraham Z, Kagan E, editors. Dead Sea Transform Fault System: Reviews. Heidelberg: Springer. p 279-316.

Stein M. 2014b. Late quaternary limnological history of Lake Kinneret. In: Zohary T, Sukenik A, Berman T, Nishri A, editors. Lake Kinneret: Ecology and Management. Dordrecht: Springer. p 39-58.

Stein M, Torfstein A, Gavrieli I, Yechieli Y. 2010. Abrupt aridities and salt deposition in the post-glacial Dead Sea and their north Atlantic connection. Quaternary Science Reviews 29(3-4):567-75.

Toffolo MB, Arie E, Martin MAS, Boaretto E, Finkelstein I. 2014. Absolute chronology of Megiddo, Israel, in the late Bronze and Iron Ages: high-resolution radiocarbon dating. Radiocarbon 56(1):221-44.

van den Brink ECM, Braun E. 2002. Wine jars with sereks from Early Bronze Lod: Appellation Vallee du Nil Controlee, but for whom? In: van den Brink ECM, Yannai E, editors. In Quest of Ancient Settlements and Landscapes: Archaeological Studies in Honour of Ram Gophna. Tel Aviv: Tel Aviv University. p 167-87.

van den Brink ECM, Levy TE, editors. 2002. Egypt and the Levant: Interrelations from the 4th through the Early 3rd Millennium B.C.E. London: Continuum.

van Zeist W, Bottema S. 2009. A palynological study of the Acheulian site of Gesher Benot Ya'aqov, Israel. Vegetation History and Archaeobotany 18(2):10521.

van Zeist W, Baruch U, Bottema S. 2009. Holocene 
palaeoecology of the Hula area, northeastern Israel. In: Kaptijn K, Petit LP, editors. A Timeless Vale. Archaeological and Related Essays on the Jordan Valley in Honour of Gerrit Van Der Kooij on the Occasion of his Sixty-Fifth Birthday. Leiden: Leiden University Press. p 29-64.

Ward WA, Joukowsky M. 1992. The Crisis Years: The 12th Century BC: From Beyond the Danube to the Tigris. Dubuque: Kendall Hunt.

Weinstein-Evron M. 1983. The paleoecology of the early Wurm in the Hula basin, Israel. Paléorient 9:5-19.

Weinstein-Evron M, Lev-Yadun S. 2000. Palaeoecology of Pinus halepensis in Israel in the light of palaeoecological and archeobotanical data. In: Ne'eman G, Trabaud L, editors. Ecology, Biogeography, and Management of Pinus halepensis and P. brutia Forest Ecosystems in the Mediterranean Basin. Leiden: Backhuys Publishers. p 119-30.

Weiss B. 1982. The decline of Late Bronze Age civilization as a possible response to climatic change. $\mathrm{Cli}$ matic Change 4(2):173-98.

Zaccagnini C. 1995. War and famine at Emar. Orientalia 64:92-109.

Zangvil A, Druian P. 1990. Upper air trough axis orienta- tion and the spatial distribution of rainfall over Israel. International Journal of Climatology 10:57-62.

Zertal A. 2004. The Manasseh Hill Country Survey: The Shechem Syncline. Leiden: Brill.

Zertal A. 2007. The Manasseh Hill Country Survey 2. Leiden: Brill.

Ziv B, Dayan U, Kushnir Y, Roth C, Enzel Y. 2006. Regional and global atmospheric patterns governing rainfall in the southern Levant. International Journal of Climatology 26:55-73.

Zohary D, Spiegel-Roy P. 1975. Beginnings of fruit growing in the old world. Science 187(4174):319-27.

Zohary D, Hopf M, Weiss E. 2012. Domestication of Plants in the Old World: The Origin and Spread of Domesticated Plants in Southwest Asia, Europe, and the Mediterranean Basin. Oxford: Oxford University Press.

Zohary M. 1962. Plant Life of Palestine. New York: Ronald Press.

Zohary M. 1973. Geobotanical Foundations of the Middle East. Stuttgart: G. Fischer.

Zohary M. 1982. Plants of the Bible - A Complete Handbook. Cambridge: Cambridge University Press. 